KS. KAZIMIERZ PANUŚ

\title{
Sprawozdanie prezesa Polskiego Towarzystwa Teologicznego za rok 2013
}

Poprzednie walne zebranie Polskiego Towarzystwa Teologicznego odbyło się 26 lutego 2013 roku. Obejmowało ono część sprawozdawczą za rok 2012 oraz udzielenie absolutorium zarządowi za tenże rok. W drugiej części walnego zebrania wręczono medal „Zasłużony dla Polskiego Towarzystwa Teologicznego" ks. prof. dr. hab. Adamowi Kubisiowi i prof. dr. hab. Franciszkowi Adamskiemu, który w dalszej części zebrania wygłosił wykład pt. Czy rodzina ma przyszłośc?

\section{Stan towarzystwa}

Rok 2013 był trzecim rokiem działalności zarządu Towarzystwa wybranego 23 lutego 2011 na trzyletni okres. Działał on w następującym składzie:

\section{Zarząd}

Prezes: ks. prof. dr hab. Kazimierz Panuś

Wiceprezes: ks. dr hab. Roman Kuligowski, prof. UKSW

Sekretarz: ks. mgr Kazimierz Moskała

Skarbnik: ks. dr Andrzej Mojżeszko

Bibliotekarz: ks. dr hab. Jan Bednarczyk

Kierownik Sekcji Wydawniczej: mgr Sebastian Wojnowski 
Komisja rewizyjna

Przewodniczący: ks. prof. dr hab. Tomasz Jelonek

Członkowie: ks. dr Sylwester Jędrzejewski SDB, ks. dr Artur Kardaś CR

\section{Sąd polubowny}

Przewodniczący: ks. prof. dr hab. Jacek Urban

Członkowie: o. prof. dr hab. Tomasz Dąbek OSB, ks. dr hab. Stanisław Hałas SCJ, prof. UPJPII

Z końcem 2013 roku Polskie Towarzystwo Teologiczne liczyło 903 członków. W roku sprawozdawczym przyjęto do towarzystwa 17 osób, w tym 4 do Oddziału w Szczecinie. Od poprzedniego walnego zebrania do wiekuistego domu Ojca odeszli (według posiadanych informacji): kard. prof. dr hab. Stanisław Nagy SCJ, ks. prof. dr hab. Stanisław Włodarczyk, ks. dr Zenon Mońka, ks. dr Zygmunt Zaborski (z oddziału częstochowskiego), ks. dr Jerzy Woźniak CM, ks. mgr Jan Palusiński SDB, ks. Stanisław Stodolak z Przemyśla oraz mgr Anna Zawodniak (doktorantka Uniwersytetu Papieskiego Jana Pawła II w Krakowie, zginęła tragicznie w Tatrach w marcu 2012).

Spełniając wymogi statutowe Zarząd odbył w roku sprawozdawczym cztery zebrania w dniach: 24 kwietnia 2013, 23 września 2013, 19 listopada 2013 i 25 lutego 2014.

Podczas pierwszego zebrania wysłuchano wykładu o. dr. hab. Romualda Kośli OFM pt. Niektóre aspekty mariologii w kazaniach św. Bernardyna ze Sieny. Zarząd zaaprobował zamiar powołania nowej sekcji specjalistycznej poświęconej teologii życia konsekrowanego. Jej organizację powierzono s. dr hab. Adelajdzie Sielepin CHR. Omówiono także wysiłki na rzecz rozszerzenia działalności na nowe diecezje. W tym kontekście poruszony został problem współpracy z towarzystwami naukowymi w Płocku i w Drohiczynie.

Drugie zebranie zarządu rozpoczął wykład ks. dr. hab. Andrzeja Nowickiego pt. Serce jako wiarygodne kryterium miłości. Omówiono formy uczczenia 90. rocznicy założenia Polskiego Towarzystwa Teologicznego, 
które powstało we Lwowie 23 lutego 1924 roku. Uchwalono, że rok 2014 towarzystwo będzie obchodzić jako swój rok jubileuszowy. Kulminacyjnym wydarzeniem uczczenia tej rocznicy będą walne zebrania w 2014 (otwierające) i 2015 (zamykające jubileusz). Zatwierdzono nowego kierownika Oddziału w Radomiu. Jest nim ks. dr hab. Marek Jagodziński. Omówiono realizację projektu pt. Nadanie międzynarodowego charakteru kwartalnikowi „Ruch Biblijny i Liturgiczny”.

Trzecie zebranie zarządu w roku sprawozdawczym odbyło się w 19 listopada 2013 roku w kolegiacie uniwersyteckiej św. Anny w Krakowie. Uroczystą mszą świętą przy konfesji św. Jana z Kęt, patrona Polskiego Towarzystwa Teologicznego, rozpoczęto obchody roku jubileuszowego 90-lecia istnienia PTT. Mszę świętą pod przewodnictwem ks. inf. prof. Andrzeja Offmańskiego, kierownika oddziału szczecińskiego koncelebrowali kapłani należący do zarządu towarzystwa. Miłosierdziu Bożemu polecono zmarłych członków towarzystwa oraz modlono się o błogosławieństwo Boże na dalsze lata pracy PTT. Po mszy świętej wykład pt. Program ideowy dekoracji kolegiaty uniwersyteckiej św. Anny w Krakowie wygłosił prof. Tomasz Węcławowicz, kierownik Sekcji Sztuki Sakralnej. Podczas obrad zarządu poruszono formy uczczenia roku jubileuszowego 90-lecia istnienia PTT (wydanie księgi pamiątkowej, upowszechnienie informacji o PTT w mediach). Omówiono także wkład PTT w kanonizację Jana Pawła II. Postanowiono, by pierwszy zeszyt kwartalnika „Ruch biblijny i liturgiczny” za rok 2014 wydawanego przez Polskie Towarzystwo Teologiczne poświęcony był różnym aspektom życia i działalności Karola Wojtyły - Jana Pawła II. S. prof. Adelajda Sielepin zreferowała zarządowi podjęte wysiłki na rzecz powołania Sekcji Teologii Życia Konsekrowanego, która swymi poszukiwaniami badawczymi będzie się dzieliła na łamach czasopisma „Via Consecrata”. W końcowej części zebrania przyjęto do PTT 9 nowych członków z różnych stron Polski.

Na czwartym przewidzianym przez statut zebraniu zarządu, które odbyło się w dniu 25 lutego 2014 roku, powołano Oddział we Włocławku. Jego kierownikiem został ks. dr. hab. Lech Król. Wyrażono także zgodę na powstanie Oddziału w Pelplinie. Koordynatorem tych prac jest ks. dr hab. Janusz Szulist. Podczas czwartego zebrania zarządu powołano także do życia Sekcję Teologii Życia Konsekrowanego i powierzono 
jej prowadzenie s. prof. Adelajdzie Sielepin. Omówiono także zasady finansowania działalności upowszechniającej naukę, z którego Polskie Towarzystwo Teologiczne może korzystać jako podmiot działający na rzecz nauki, prowadzenie strony internetowej oraz konferencje naukowe organizowane przez PTT w roku 2014.

\section{Działalność towarzystwa}

W ramach Polskiego Towarzystwa Teologicznego działa Studium Syndonologiczne, 15 sekcji specjalistycznych i 14 oddziałów terenowych oraz Sekcja Wydawnicza prowadząca Wydawnictwo UNUM.

\subsection{Studium Syndonologiczne}

Studium Syndonologiczne Polskiego Towarzystwa Teologicznego moderował ks. doc. dr hab. Jerzy Chmiel. W roku sprawozdawczym, na skutek choroby moderatora, spotkania nie odbywały się.

\subsection{Sekcja Biblijna}

Kierownikiem sekcji jest ks. dr hab. Roman Bogacz. W roku sprawozdawczym sekcja zorganizowała dwa spotkania. Pierwsze pod hasłem Czerpiąc sily z wiary przodków wpatrzeni w przyszłość odbyło się 18 czerwca w Morawicy. Jego uczestnicy mieli możliwość zobaczenia ważnych miejsc historycznych i porozmawiania o kwestiach związanych z pracami sekcji. Spotkanie miało także charakter integracyjny. Drugie spotkanie odbyło się 20 listopada w ramach sympozjum naukowego pt. Wiara $i$ jej przekaz w Piśmie Świętym zorganizowanego z okazji Roku Wiary przez Sekcję Biblijną wraz z Instytutem Nauk Biblijnych Wydziału Teologicznego Uniwersytetu Papieskiego Jana Pawła II w Krakowie. Referaty dotyczyły zagadnień wiary w Biblii: z punktu widzenia konkretnego człowieka (Kryzys wiary psalmisty - ukazany przez ks. dr. Wojciecha Węgrzyniaka), poprzez zagadnienia związane $\mathrm{z}$ wiarą $\mathrm{w}$ Jezusa Chrystusa ukazywanego w Ewangeliach i problemami racjonalistów ze szkoły Rudolfa Bultmanna 
(ks. dr Stanisław Wronka), po bardzo głębokie podjęcie tematu wiary przez autora Listu do Hebrajczyków, który ukazał wiarę w Syna Bożego oraz przykłady wiary starożytnych. W drugiej części sympozjum podjęto wątek przekazu wiary, czyli ewangelizacji, kwestię świadectwa aż po męczeństwo oraz problemy przekazu wiary i wyboru odpowiednich metod w katechezie biblijnej. Tego typu spotkania mają charakter święta Biblii w naszym środowisku.

\subsection{Sekcja Teologii Moralnej}

Sekcję prowadzi ks. dr Bogusław Mielec. W roku sprawozdawczym sekcja zorganizowała 21 maja wraz z innymi podmiotami (m.in. z Sekcją Pedagogiczno-Katechetyczną) kolejne sympozjum z cyklu Na skrzyżowaniu dróg. Teologia moralna i pedagogika, którego tematem były Kryteria wychowania chrześcijańskiego. Wykłady i dyskusje dotyczyły znaków rozpoznawczych wychowania chrześcijańskiego w Biblii, Tradycji oraz w teologii moralnej. Osobny segment stanowiły wystąpienia ściśle pedagogiczne poświęcone poszukiwaniu tych kryteriów w szeroko rozumianej pedagogice (zwłaszcza w kontekście cywilizacji medialnej). Materiały z tego sympozjum zostaną ukażą się w publikacji.

\subsection{Sekcja Homiletyczna}

Przewodniczącym sekcji jest ks. prof. dr hab. Kazimierz Panuś. W roku sprawozdawczym 2013 Sekcja Homiletyczna poświęciła wiele uwagi kaznodziejstwu abp. Józefa Teodorowicza z racji 75. rocznicy śmierci tego ostatniego ormiańsko-katolickiego arcybiskupa Lwowa. W związku z tym 7 grudnia 2013 roku kierownik sekcji wygłosił wykład pt. Myśl Boża względem Polski - kaznodziejstwo abp. Józefa Teofila Teodorowicza podczas konferencji naukowej pt. Arcybiskup Józef Teofil Teodorowicz (1864-1938). Pasterz Kościoła ormiańskiego w Polsce, mąż stanu, kaznodzieja, pisarz. Konferencja ta wpisana była w Tydzień pamięci o ormiańskim arcybiskupie i polskim patriocie - Józefie Teodorowiczu. Kierownik Sekcji Homiletycznej uczestniczył też 10 kwietnia 2013 roku w ogólnopolskim sympozjum mariologiczno-maryjnym Jasnogórska Szkoła Wiary 
zorganizowanym przez klasztor Paulinów na Jasnej Górze przy współpracy Uniwersytetu Papieskiego Jana Pawła II w Krakowie, wygłaszając wykład: Jasnogórska szkoła wiary wyzwaniem do nowej ewangelizacji.

\subsection{Sekcja Socjologiczno-Pastoralna}

Sekcja, którą kieruje ks. dr Stefan Dobrzanowski, skupia 16 naukowców z dziedziny socjologii, katolickiej nauki społecznej i teologii pastoralnej, działających głównie w środowiskach naukowych Krakowa, Warszawy i Lublina. W roku sprawozdawczym sekcja zorganizowała dwa posiedzenia naukowe. Pierwsze z nich 14 października miało charakter organizacyjny i poświęcone było organizacji sesji nt. upowszechniania ideologii gender w Europie. Drugie spotkanie odbyło się w 13 grudnia w Grocie św. Eliasza przy klasztorze Karmelitów na Piasku w Krakowie. W jego trakcie poruszono aktualne sprawy z życia Kościoła i badań socjologicznych religijności, a wykład pt. Integralna wizja człowieka i jej wrogowie wygłosił prof. Franciszek Adamski. W ożywionej dyskusji poruszono zagrożenia dla człowieka, rodziny i małżeństwa wynikające ze strony ideologii gender.

\subsection{Sekcja Duchowości}

Kierownikiem sekcji jest ks. prof. dr hab. Wojciech Misztal. Sekcja kontynuowała prace związane $\mathrm{z}$ wieloletnim programem badań naukowych pt. Duchowość klasztorów polskich: przekaz i komunikacja. Jej efektem było zorganizowanie dwóch sympozjów na ten temat: 9 lutego - Zapatrzona w Boga i wsłuchana w człowieka. Św. Aniela Merici i jej dzieło realizowane przez z Urszulanki Unii Rzymskiej oraz 12 lutego - Misja bułgarska zmartwychwstańców: 150 lat w służbie Kościołowi i społeczeństwu. Materiały z tych konferencji ukazały w publikacjach. W realizacji tych przedsięwzięć uczestniczyli przedstawiciele środowisk naukowych z całego kraju, osoby świeckie i duchowne. Przyczynia się to do integracji środowiska naukowego i zaznajamiania z potencjałem środowiska Uniwersytetu Papieskiego Jana Pawła II w Krakowie i Polskiego Towarzystwa Teologicznego. Zaawansowane są prace nad VIII sympozjum 
z cyklu Duchowość klasztorów polskich: przekaz i komunikacja, które poświęcone będzie Dziennikowi ks. Piotra Semenenki.

\subsection{Sekcja Pedagogiczno-Katechetyczna}

Kierownikiem sekcji jest ks. prof. dr hab. Janusz Mastalski. W roku sprawozdawczym sekcja zorganizowała wraz z Wyższym Seminarium Duchownym w Krakowie ogólnopolskie Forum penitencjarne (23 kwietnia 2013), a wraz z Sekcją Teologii Moralnej konferencję Kryteria chrześcijańskiego wychowania (21 maja 2013).

\subsection{Sekcja Dogmatyczna}

Kierownikiem sekcji jest ks. dr hab. Jan Żelazny, prof. UPJPII. W roku sprawozdawczym sekcja przyjęła nowych członków z różnych ośrodków akademickich w Polsce. Na uwagę zasługują regularne comiesięczne spotkania członków sekcji poświęcone badaniom nad antykiem chrześcijańskim. Uczestniczy w nich około 15 osób, członków sekcji z Opola, Katowic, Tarnowa, Lublina, Krakowa i Kalwarii. Trwają prace nad organizacją sympozjum na temat wolności w myśli wschodnio-chrześcijańskiej.

\subsection{Sekcja Misjologiczna}

Pracami sekcji w ścisłej współpracy ze Stowarzyszeniem Misjologów Polskich i Papieskimi Dziełami Misyjnymi Archidiecezji Katowickiej kieruje ks. dr Grzegorz Wita. W ramach działalności Sekcji Misjologicznej 20 kwietnia został zorganizowany w Katowicach-Panewnikach II Kongres Misyjny Archidiecezji Katowickiej, w którym wzięło udział ponad 650 uczestników. W programie znalazły się także wykłady i dyskusje misjologiczne dla dorosłych i dla młodzieży. 8 czerwca odbył się XI Rajd Misyjny Dzieła Misyjnego Archidiecezji Katowickiej w Ustroniu współorganizowany przez członków sekcji. Wzięło w nim udział ponad 200 uczestników. W dniach 25 czerwca-6 lipca nad Jeziorem Wiktorii w Musoma w Tanzanii (Afryka) zostało zorganizowane I Spotkanie Śląskich Misjonarzy Fideidonistów. W dniach 15-21 lipca 2013 roku kierownik 
sekcji uczestniczył w V Międzynarodowej Konferencji pt. Missio inter-gentes - wyzwania i okoliczności zorganizowanej przez International Association of Catholic Missiologists na Catholic University of Eastern Africa w Nairobi (Kenia). W dniu 20 lipca wystąpił z referatem Mutual Hospitality of Religions. W dniach 8-10 września w Wyższym Seminarium Duchownym Diecezji Zielonogórsko-Gorzowskiej w Paradyżu odbyła się konferencja misjologiczna zorganizowana przez Stowarzyszenie Misjologów Polskich, w której udział wzięli członkowie Sekcji Misjologicznej, a 19 października w Rybniku odbyła się II pielgrzymka środowisk różańcowych archidiecezji katowickiej, podczas której ks. dr Grzegorz Wita wygłosił referat Żywy Różaniec dla misji. Ks. dr Grzegorz Wita przewodniczył pracom Komisji ds. Ewangelizacji II Synodu Archidiecezji Katowickiej. Zostało także przeprowadzonych osiem comiesięcznych spotkań formacyjnych o tematyce misyjnej dla księży archidiecezji katowickiej, nadto liczne spotkania formacyjne oraz niedziele misyjne, którym towarzyszyły wykłady i spotkania. W duchu solidarności z chrześcijanami z Ziemi Świętej realizowany był projekt Głosimy Jezusa ukrzyżowanego, który umocnił świadomość powszechności Kościoła i odpowiedzialności za niego oraz wspierał zakup samochodów dla misjonarzy. Członkowie sekcji opublikowali też kilka pozycji książkowych i artykułów.

\subsection{Sekcja Prawa Kanonicznego}

Kieruje nią o. dr Andrzej Kukła CSsR. W roku sprawozdawczym członkowie sekcji organizowali i uczestniczyli w kilku ważnych sympozjach, takich jak: Międzynarodowe spotkanie pt. Il Codice: una riforma voluta e richiesta dal Concilio 30 anni dopo la promulgazione del Codice di Diritto Canonico. Una Giornata di studio promossa dal Pontincio Consiglio per $i$ Testi Legislativi e dallİstituto Internazionale di Diritto Canonico e Diritto comparato delle Religioni di Lugano (Rzym, 25 stycznia 2013); Contemporary Challanges for International Law-Human Rights Protection, Combating Terrorism and Prosecution of International Criminals (Katolicki Uniwersytet Lubelski Jana Pawła II, 15 kwietnia 2013); sympozjum pt. Wiarę wyznawać, celebrować, przeżywać (Kraków, 22 maja 2013); Międzynarodowa Konferencja Naukowa Kanonistów pt. Przynależność do 
Kościoła a uczestnictwo wiernych $w$ życiu publicznym (Kielce, 5-7 września 2013); XIII Konferencja Rola Kościoła katolickiego w procesie integracji europejskiej pod hasłem Rodzina we współczesnej Europie (Kraków, 13-14 września 2013) oraz sympozjum Czy polski Konkordat faworyzuje Kościót katolicki? (Kraków, 14 listopada 2013). W ramach sekcji miały miejsce spotkania i konsultacje z o. dr. hab. Markiem Sajem CSsR, wykładowcą UKSW. Kierownik sekcji o. dr Andrzej Kukła podjął wykłady z prawa na Univesita' della Svizzera Italiana w Lugano (Szwajcaria) i dzięki temu nawiązała się nowa współpraca $z$ gronem profesorskim i studentami tegoż uniwersytetu, z prof. Libero Gerosą - dziekanem wydziału prawa na czele. Podejmowane są nadal próby nawiązania bliższych kontaktów naukowych z kanonistami z UKSW w Warszawie.

\subsection{Sekcja Liturgiczna}

Sekcję prowadzi ks. dr Stanisław Mieszczak SCJ. W roku sprawozdawczym członkowie Sekcji podejmowali formację liturgiczno-pastoralną młodzieży, wiernych i duchownych. Ważnym sektorem jest formacja służby liturgicznej, nadzwyczajnych szafarzy komunii świętej, fotografów i innych grup. We współpracy z bp. prof. Wacławem Świerzawskim sekcja wydała ośmiotomowy podręcznik liturgiki ogólnej i szczegółowej pt. Misterium Christi. W roku 2012 wyszły trzy tomy: Fundamentalne rzeczywistości liturgii, Historia liturgii i Msza święta. W 2013 wyszło pięć tomów: Sakramenty i sakramentalia, Liturgia uświęcenia czasu, Rok liturgiczny, Sztuka w liturgii i Formacja liturgiczna. Dzieło to jest zbiorem artykułów wszystkich polskich liturgistów i zostało opracowane we współpracy z Ośrodkiem Formacji Liturgicznej w Zawichoście. W dniach 23-24 października Sekcja Liturgiczna zorganizowała międzynarodowe sympozjum liturgiczne z cyklu Ad fontes liturgicos pt. Reformy liturgii a powrót do źródeł. Pod patronatem Instytutu Liturgicznego przywrócono dwuletnie Studium Katechumenalne, które przygotowuje do formacji w procesie chrześcijańskiego wtajemniczenia dorosłych. Zorganizowano spotkanie ekumeniczne na temat liturgii św. Jana Chryzostoma związane z promocją książki ks. prof. Stefana Koperka pt. Rekolekcje ze św. Janem Chryzostomem. Rozważania na kanwie Boskiej liturgii. Kierownik sekcji 
wygłosił referat na II Konferencji Naukowej pt. Liturgia i teologia chrztu od starożytności chrześcijańskiej do czasów nowożytnych zorganizowanym przez Instytut Kultury Europejskiej Uniwersytetu Adama Mickiewicza w Gnieźnie oraz Muzeum Pierwszych Piastów na Lednicy z okazji obchodów 1050. rocznicy chrztu Polski (11-12 czerwca) oraz na Kongresie Societas Liturgica pt. Liturgical Reforms in the Churches (5-13 sierpnia, Würzburg). Podjęto także wykłady z teologii liturgii w Instytucie Johna Newmana w Uppsali (25-31 listopada).

\subsection{Sekcja Sztuki Sakralnej}

Sekcją kieruje dr hab. Tomasz Węcławowicz, prof. KAAFM. W roku sprawozdawczym działania sekcji koncentrowały się na naukowych i popularno-naukowych wystąpieniach dotyczących zarówno badań architektoniczno-konserwatorskich w średniowiecznych kościołach Krakowa, jak i treści historycznej architektury sakralnej rozumianej jako tzw. tekst kultury. W marcu podczas Konferencji Naukowej pt. Forum Architecturae Poloniae Medievalis kierownik sekcji wygłosił referat pt. Architektoniczny palimpsest zespołu klasztornego w Mogile, który był przygotowany dzięki pomocy członka sekcji o. Mateusza Kawy OCist (tekst referatu został opublikowany przez Politechnikę Krakowską, a rezultaty szczegółowych badań konserwatorskich murów kościoła zostały opublikowane w obszernej książce autorstwa kierownika sekcji pt. Cocto latere nobilitavit: Ceglane mury średniowiecznych kościołów Krakowa). W kwietniu w związku z konferencją w Muzeum Historycznym Miasta Krakowa pt. Kraków romański kierownik sekcji został poproszony o przygotowanie referatu w panelu wprowadzającym pt. Topographia sacra romańskiego Krakowa (publikacje materiałów pokonferencyjnych przygotowuje aktualnie Towarzystwo Miłośników Historii i Zabytków Krakowa). W październiku dr Ales Pospisil zorganizował w Kutnej Horze spotkanie dla krakowskich konserwatorów zabytków sakralnych, prezentując rezultaty swoich prac w kościele św. Barbary. W listopadzie i w grudniu w związku z 310. rocznicą konsekracji kościoła św. Anny w Krakowie kierownik sekcji wygłosił krótkie referaty o treściach ikonograficznych dekoracji malarskiej i rzeźbiarskiej tego kościoła dla uczestników okolicznościowej 
konferencji naukowej i oddzielnie dla członków zarządu PTT. W drugim półroczu minionego roku kierownik sekcji opracował materiały do swej książki przygotowanej na 650. rocznicę konsekracji katedry wawelskiej. Książka ta poprzedzona słowem wstępnym kard. Stanisława Dziwisza będzie wkładem sekcji w ten jubileusz, który zbiega się z jubileuszem 90-lecia Polskiego Towarzystwa Teologicznego.

\subsection{Sekcja Filozoficzna}

Kierownikiem sekcji jest ks. dr hab. Henryk Majkrzak SCJ. W roku sprawozdawczym zorganizowano 2 sesje naukowe: 8 czerwca - ku czci św. Jadwigi (wraz z Instytutem św. Jadwigi Królowej działającym przy klasztorze Karmelitów Na Piasku w Krakowie), w trakcie której kierownik sekcji wygłosił referat pt. Cnota mądrości w życiu św. Jadwigi królowej Polski oraz 19 października w Wyższym Seminarium Duchownym Księży Sercanów w Stadnikach na temat Przyczyny filozofowania. Ponadto kierownik sekcji wygłosił 12 marca w Katolickim Uniwersytecie Lubelskim Jana Pawła II wykład pt. Święty Tomasz z Akwinu jako człowiek, filozof i teolog, a 12 grudnia reprezentował Sekcję Filozoficzną PTT na międzynarodowym sympozjum pt. Spór o naturęludzka zorganizowanym przez Katedrę Metafizyki Katolickiego Uniwersytetu Lubelskiego Jana Pawła II. Zbliżającą się kanonizację papieża Jana Pawła sekcja uczci, wydając książkę o heroizmie wiary papieża Polaka.

\subsection{Sekcja Teologii Fundamentalnej}

Kierownikiem sekcji jest ks. dr Damian Wąsek. W roku sprawozdawczym 2013 przedstawiciele Sekcji Teologii Fundamentalnej organizowali, współorganizowali, bądź brali udział w wielu wydarzeniach naukowych. Angażowali się w sposób szczególny w inicjatywy o charakterze ekumenicznym i apologetycznym. Do najważniejszych dokonań należy zorganizowanie przez o. prof. dra hab. Andrzeja Napiórkowskiego sympozjum: Koncepcje teologii katolickiej (28 lutego), referat kierownika sekcji pt. Foundations of the definition of faith in dialogue with Porta Fidei by Benedict XVI wygłoszony podczas konferencji: Lascolto della Parola 
di Dio, l'ascolto dell'altro (17 kwietnia), wystąpienie dr hab. Marka Kity pt. Słowo Boże a dialog międzyreligijny podczas konferencji: Debata wokół słowa (19 kwietnia), o. prof. Andrzeja Napiórkowskiego pt. Co Duch Święty mówi do Kościoła? (por. Ap 2, 7). Sobór jako odpowiedź wiary na Słowo Boga podczas konferencji: Wiarę wyznawać, przeżywać, celebrować (22 maja) oraz Damiana Wąska z referatem Dziedzictwo mistrzów podejrzeń w Nowym Ateizmie podczas konferencji: Mistrzowie podejrzeń: negacja, afirmacja czy przezwyciężenie? (20 grudnia). Wydarzenia te poprzedzane były spotkaniami i konsultacjami członków sekcji. Równocześnie toczyły się spotkania wokół głównych tematów teologii fundamentalnej. Członkowie sekcji opublikowali szereg artykułów naukowych i książek.

\subsection{Sekcja Historyczna}

Jej pracami kieruje ks. prof. dr hab. Józef Marecki. W roku sprawozdawczym sekcja nie złożyła sprawozdania.

\section{Oddziały terenowe}

Polskie Towarzystwo Teologiczne w Krakowie działa także poprzez oddziały terenowe.

\subsection{Oddział w Katowicach}

Pracami oddziału liczącego obecnie 19 członków kieruje ks. dr hab. Andrzej Nowicki. W roku sprawozdawczym odbyły się dwa zebrania. Pierwsze 25 marca w sali Regionalnej Izby Gospodarczej w Katowicach zgromadziło oprócz członków oddziału katowickiego PTT także przedstawicieli świata gospodarki, kultury i mediów. W ramach tego spotkania wykład pt. Polityka spójności Unii Europejskiej wygłosił poseł do Parlamentu Europejskiego dr Jan Olbrycht. Drugie spotkanie członków Sekcji Polskiego Towarzystwa Teologicznego w Katowicach miało miejsce 21 października w ramach konferencji stanowiącej podsumowanie roku kard. Augusta Hlonda. Podczas tej konferencji referat na temat: Wymiar 
mariologiczny zawarty $w$ duszpasterskim programie kard. Augusta Hlonda wygłosił ks. dr Henryk Olszar (Uniwersytet Śląski).

\subsection{Oddział w Częstochowie}

Pracami oddziału kieruje ks. dr Jerzy Bielecki. W roku sprawozdawczym odbyły się 2 zebrania zarządu oddziału: 6 maja członkowie PTT uczestniczyli w prezentacji książki ks. dr Teofila Siudego pt. Matka naszego zawierzenia (dokonał jej ks. dr Jerzy Bielecki - kierownik częstochowskiego oddziału). 14 grudnia 2013 roku częstochowski oddział PTT współorganizował konferencję z okazji 45. rocznicy encykliki papieża Pawła VI Humanae Vitae oraz 30. rocznicy Karty Praw Rodziny pt. Gender - wyraz postępu czy śmiertelne zagrożenie dla cywilizacji życia i miłości. $\mathrm{Na}$ zakończenie konferencji odbył się panel dyskusyjny z udziałem profesorów - członków częstochowskiego oddziału PTT.

\subsection{Oddział w Przemyślu}

Pracami oddziału liczącego 38 członków kieruje ks. dr hab. Wacław Siwak. W okresie sprawozdawczym odbyły się trzy zebrania członków i sympatyków oddziału: 14 lutego z referatem ks. dr. Tadeusza Bratkowskiego pt. Muzyka liturgiczna w pismach i wypowiedziach kard. Ratzingera - pap. Benedykta XVI, 12 czerwca z referatem ks. dr. Arkadiusza Jasiewicza pt. Prezbiterium w okresie po-apostolskim. Przyczynek do dyskusji oraz 18 grudnia z prezentacją książek ks. dr. Norberta Podhoreckiego pt. The dispute about the truth in the globalized world (Przemyśl 2013) i Ks. Aleksander Pawłowski, jodłowski proboszcz 1899-1932. Miejsce, osoba, dzieło, red. B. Majchrowicz, W. Siwak (Jodłówka-Rzeszów 2013) będącej pokłosiem sympozjum o tym samym tytule, które odbyło się 29 czerwca w sanktuarium maryjnym w Jodłówce. Wszystkim spotkaniom towarzyszyła ożywiona dyskusja.

\subsection{Oddział w Kalwarii Zebrzydowskiej}

Kieruje nim o. dr hab. Romuald Kośla OFM. W roku sprawozdawczym Oddział w Kalwarii Zebrzydowskiej działający przy Wyższym Seminarium 
Duchownym Ojców Bernardynów zorganizował trzy spotkania. 15 marca odbyła się w Kalwarii Zebrzydowskiej sesja naukowa pod ogólnym tytułem: O wierze i zagadnieniach z niej wypływajacych, podczas której wygłoszono 4 referaty: Wiara w Biblii, zagadnienia wybrane (dr Edmund Świerczek OFM), Św. Bonawentura i bł. Jan Duns Szkot wokół zagadnień dotyczacych wiary (dr hab. Romuald H. Kośla OFM), Małżeństwo a tzw. związki partnerskie w aspekcie prawa kanonicznego i świeckiego (dr Tytus Fułat OFM) oraz O ochronie życia poczętego (dr inż. Antoni Zięba). Drugie spotkanie oddziału odbyło się 8 listopada $z$ racji inauguracji roku akademickiego 2013/2014 w Wyższym Seminarium Duchownym Ojców Bernardynów. Podczas uroczystości wykład pt. Pierworodny z całego stworzenia wygłosił ks. prof. dr hab. Tomasz Jelonek. Trzecie spotkanie 9 listopada poświęcone było dwudziestoleciu działalności Wyższego Seminarium Duchownego Bernardynów w nowym budynku w Kalwarii Zebrzydowskiej. Podczas sesji naukowej przedstawione zostały 4 referaty przybliżające budowę klasztoru i seminarium oraz różne aspekty podejmowanej w nim działalności.

\subsection{Oddział w Tuchowie}

Kieruje nim o. dr Janusz Urban CSsR. W roku sprawozdawczym oddział w Tuchowie był współorganizatorem sympozjum misyjno-pastoralnego Redemptoryści świadkami obfitego odkupienia w Roku Wiary (29-31 stycznia), które składało się z części modlitewnej, formacyjnej i informacyjnej. Referaty na tematy świętości Jezusa i jej głoszenia, zdolności rozumu do poznania prawdy oraz słynnego misjonarza sługi Bożego o. Bernarda Łubieńskiego CSsR wygłosili ks. dr hab. Janusz Królikowski, prof. UPJPII, ks. dr hab. Tadeusz Guz, prof. KUL oraz o. dr Paweł Drobot CSsR z Krakowa. 18 kwietnia zorganizowano spotkanie z dr. Antonim Ziębą na temat aktualnego stanu prawnego ochrony życia w Polsce i jego perspektyw. W dniach 11-12 października odbyło się sympozjum naukowe nt. W stużbie obfitego odkupienia zorganizowane z okazji 130. rocznicy powrotu redemptorystów na ziemie polskie oraz 80 . rocznicy śmierci sługi Bożego o. Bernarda Łubieńskiego CSsR. Wygłoszone referaty koncentrowały się wokół postaci sławnego kaznodziei. W trakcie 
sympozjum odbyła się też premiera filmu dokumentalnego poświęconego jego życiu. W dniach 4-6 listopada odbyły się w Tuchowie warsztaty homiletyczne pt. Sztuka prezentacji słowa prowadzone przez Krzysztofa Najdowskiego z Augsburga w Niemczech. Miały one na celu zwiększenie efektywnego przekazu słowa zgodnie z zasadami komunikacji werbalnej i niewerbalnej.

\subsection{Oddział w Kielcach}

Pracami oddziału kieruje ks. dr Paweł Borto. W roku sprawozdawczym odbywały się regularne comiesięczne spotkania, na których dzielono się doświadczeniami z różnych konferencji naukowych i ważnych wydarzeń kulturalnych. Ponadto na szczególną uwagę zasługuje konferencja z cyklu Sacrum $w$ kulturze zorganizowana przez oddział kielecki podczas XVI Międzynarodowej Wystawy Budownictwa i Wyposażenia Kościołów, Sztuki Sakralnej i Dewocjonaliów SACROEXPO. W jej trakcie wygłoszono następujące referaty: A może jednak piękno? (ks. prof. dr hab. Roman Kuligowski, wiceprezes PTT), Ikony rosyjskie ze zbiorów Muzeum Południowego Podlasia w Białej Podlaskiej (dyr. Małgorzata Nikolska), „Mdły umysł do prawdy przez materialne rzeczy się wznosi”. Sacrae imagines katedry kieleckiej (prof. dr hab. Marta Pieniążek-Samek), Kielecka Biblia Pauperum? Malowidła ścienne w katedrze kieleckiej (ks. dr Paweł Tkaczyk). Członkowie oddziału kieleckiego ks. Paweł Borto i ks. Tomasz Siemieniec zaangażowali się w kilkutorowe prace związane z przygotowaniem strony internetowej czasopisma „Kieleckie Studia Teologiczne”, dostosowaniem strony merytorycznej i formalnej rocznika do nowych kryteriów ewaluacji czasopism naukowych oraz stworzeniem grona recenzentów. Podczas spotkań oddziału kieleckiego jego sekretarz ks. Zbigniew Trzaskowski omówił przebieg trzech interdyscyplinarnych konferencji naukowych z cyklu Kategorie kultury: Czas jako paradygmat kultury i natury, Literatura w obszarach innych sztuk. Problemy metodologiczne oraz Święty Krzyż w twórczości wspótczesnych poetów kieleckich. Znaczącym osiągnięciem oddziału kieleckiego PTT było zainicjowanie przez ks. Andrzeja Kwaśniewskiego cyklu szkolenia przewodników po diecezji kieleckiej zaplanowanego na 3 lata. 


\subsection{Oddział w Sandomierzu}

Pracami oddziału kieruje ks. dr hab. Roman Bogusław Sieroń, prof. KUL. Oddział liczy 27 osób i działa przy Instytucie Teologicznym im. bł. Wincentego Kadłubka w Sandomierzu. W roku sprawozdawczym 2013 oddział sandomierski podjął wiele form działalności. Był organizatorem bądź współorganizatorem pięciu krajowych i międzynarodowych konferencji naukowych: Wokół chrześcijańskiego Wschodu (Sandomierz, 13 kwietnia), Dzieci i młodzież w obliczu zagrożenia patologiami społecznymi. Wychowanie, profilaktyka, terapia (Jasło, 20 kwietnia), Postmodernistyczny człowiek - pielgrzym czy emigrant ze świata kultury biblijnej (Sandomierz, 26 listopada), Profilaktyka i prewencja wobec zachowań ryzykownych młodzieży (Stalowa Wola-Tarnobrzeg, 25-26 kwietnia), sympozjum międzynarodowe $W$ trosce o rodzinę we współpracy z Instytutem Teologicznym we Lwowie (Lwów-Brzuchowice, 11 maja) oraz dwóch cykli konferencji dla kapłanów, pierwszy uwrażliwiający na znaki, postawy i gesty w celebracji Eucharystii (10-12 kwietnia), a drugi poświęcony nowej ewangelizacji w misji Kościoła i posłudze prezbitera (23-24 października). Członkowie sandomierskiego oddziału PTT wzięli również udział w 36 krajowych i zagranicznych konferencjach naukowych, wygłaszając referaty bądź prowadząc obrady. Prowadzono także wzmożoną działalność wydawniczą, czego owocem są 34 publikacje książkowe i artykuły zamieszczone w pracach zbiorowych bądź na łamach „Przeglądu Biblijnego”, „Kroniki Diecezji Sandomierskiej”, a zwłaszcza kwartalnika „Społeczeństwo i Rodzina” redagowanego przez kierownika oddziału, periodyku, który w ostatniej ewaluacji MNiSW uzyskał wysokie 8 punktów za każdy zamieszczony tam artykuł.

\subsection{Oddział w Tarnowie}

Kierownikiem oddziału jest ks. dr hab. Janusz Królikowski, prof. UPJPII. W roku sprawozdawczym kontynuowano badania nad dziejami diecezji tarnowskiej. Opublikowane prace będące owocem podjęcia tego zagadnienia obejmują już cztery tomy pod wspólnym tytułem Dzieje diecezji tarnowskiej. W roku 2014 ukaże się kolejny wolumin dotyczący dziejów 
Seminarium Duchownego w Tarnowie. Oprócz tego w stanie zaawansowanym jest tom, w którym zostaną zebrane wszystkie dokumenty papieskie łączące się z dziejami diecezji tarnowskiej. Wkrótce wydane zostaną także materiały z konferencji naukowej, która odbyła się w listopadzie 2012 roku w Mielcu dotyczącej kapłaństwa i antyklerykalizmu. Rzecz dotyczyła wspomnienia 100-lecia listu bp. Leona Wałęgi poświęconego antyklerykalizmowi i jego aktualności w naszych czasach. W listopadzie oddział tarnowski włączył się w przeprowadzenie w Mielcu Katolickich Dni Formacyjnych, których tematem była w tym roku kwestia wychowania i udziału chrześcijan w tej ważnej kwestii społecznej.

\subsection{Oddział w Rzeszowie}

Kierownikiem oddziału jest ks. dr hab. Andrzej Garbarz, prof. UR. W roku sprawozdawczym członkowie oddziału podejmowali różne inicjatywy promujące rozwój myśli teologicznej oraz przeciwdziałanie procesom dechrystianizacji i laicyzacji społecznej. Służyło temu m.in. sympozjum naukowe w Sanktuarium Matki Bożej Pocieszenia w Jodłówce (29 czerwca) pt. Ks. Aleksander Pawłowski. Jodłowiecki Proboszcz 18991932. Miejsce, osoba, dzieło, podczas którego referat nt. Rodzina w kaznodziejskim nauczaniu ks. Aleksandra Pawłowskiego wygłosił kierownik oddziału; panel dyskusyjny Jan Paweł II - papież dialogu (19 października) z udziałem m.in. Krzysztofa Zanussiego i rektora Uniwersytetu Rzeszowskiego prof. dr. hab. Aleksandra Bobko oraz 5 Międzynarodowe Seminarium Kół i ich Mentorów Rodzina - centrum świata (Rzeszów, 27 listopada), podczas którego zaprezentowany został dokument przygotowawczy do Synodu Biskupów 2014 - wstępne wyniki ankiety z diecezji rzeszowskiej. Wydano kolejny tom studiów teologiczno-filozoficznych „Resovia Sacra” poświęcony 20-leciu istnienia Wyższego Seminarium Duchownego w Rzeszowie (1993-2013). Ponadto członkowie rzeszowskiego oddziału PTT opublikowali szereg artykułów w czasopismach teologicznych i pracach zbiorowych, m.in. w miesięczniku diecezjalnym "Zwiastowanie”, oraz angażowali się w różnorodną działalność naukową i duszpasterską, m.in. prowadząc cykliczne lub autorskie audycje w Katolickim Radiu „VIA”. 


\subsection{Oddział w Bielsku-Białej}

Kierownikiem oddziału jest ks. prof. dr hab. Tadeusz Borutka. Oddział liczy aktualnie 47 członków. W roku sprawozdawczym odbyły się trzy spotkania w siedzibie Instytutu Teologicznego im. św. Jana Kantego w BielskuBiałej: 8 stycznia 2013 - spotkanie opłatkowe dla członków bielskiego oddziału PTT i środowiska akademickiego Podbeskidzia z udziałem bpa Tadeusza Rakoczego; 20 kwietnia 2013 w ramach sesji naukowej referaty wygłosili: ks. prof. Edward Staniek: Przekaz wiary w Chrystusa według św. Pawła i bp dr hab. Grzegorz Ryś: Nowa ewangelizacja dla przekazu wiary; 26 listopada 2013 wykład pt. Czy Kościół potrzebuje prawa? wygłosił ks. dr hab. Piotr Kroczek (Uniwersytet Papieski Jana Pawła II w Krakowie). Wykłady połączone były z dyskusją. Członkowie bielskiego oddziału PTT wzięli również udział w odbywającej się w dniach od 14-15 listopada 2013 roku Międzynarodowej Konferencji Naukowej Zmierzch zorganizowanej przez Instytut Teologiczny im. św. Jana Kantego w Bielsku-Białej wspólnie z Katedrą Literatury i Kultury Polskiej, Wydziału HumanistycznoSpołecznego Akademii Techniczno-Humanistycznej w Bielsku-Białej.

\subsection{Oddział w Radomiu}

Kierownikiem oddziału jest ks. dr hab. Marek Jagodziński. W roku sprawozdawczym oddział liczący obecnie 59 osób współorganizował dwie konferencje naukowe. 23 maja sesję pt. Od Soboru Watykańskiego II do nowej ewangelizacji z wykładami: Recepcia Druheho vatikanskeho koncilu slovenskymi jezuitmi (prof. ThDr. Ladislav Csontos SJ, PhD, Uniwersytet w Trnawie), Słowackie katechizmy - katecheza przed i po Soborze Watykańskim II (doc. ThDr. Andrej Filipek SJ, PhD, Uniwersytet w Trnawie), Od „Syllabusa” do „Dignitatis humanae” (prof. dr hab. Józef Kulisz SJ, Wydział Teologiczny św. Andrzeja Boboli w Warszawie), Posoborowa reforma liturgii w Kościele w Polsce (ks. dr Dariusz Skrok, Uniwersytet Kardynała Stefana Wyszyńskiego w Warszawie), Dialog Kościoła katolickiego z niewierzacymi a nowa ewangelizacja (ks. prof. Roman Kuligowski, Uniwersytet Kardynała Stefana Wyszyńskiego w Warszawie). Dyskusję panelową nt. obecności i roli Kościoła w Europie 
w świetle nauczania Vaticanum II i założeń nowej ewangelizacji poprowadził prof. Józef Kulisz SJ. Druga konferencja naukowa pt. Wiara wobec współczesności została zorganizowana na zakończenie Roku Wiary w diecezji radomskiej 20 listopada. W jej trakcie wygłoszono następujące referaty: Kulturowe uwarunkowania wiary na przykładzie aktualnej sytuacji $w$ Polsce (ks. prof. dr hab. Ignacy Bokwa, Uniwersytet Kardynała Stefana Wyszyńskiego w Warszawie), Kościół jako środowisko wiary (ks. Marek Jagodziński, kierownik oddziału) oraz Główne idee encykliki „Lumen fidei” papieża Franciszka (mgr lic. Marek Sobisz, doktorant Uniwersytetu Kardynała Stefana Wyszyńskiego w Warszawie).

\subsection{Oddział w Sosnowcu}

Kierownikiem oddziału liczącego aktualnie 36 członków jest ks. prof. dr hab. Jan Orzeszyna. W roku sprawozdawczym odbyło się łącznie pięć spotkań, w tym dwa dni skupienia z sesją wykładową, jedno spotkanie robocze zarządu, jedno omówienie obronionej rozprawy doktorskiej oraz jedno sympozjum naukowe. Dni skupienia związane były z celebracją roku liturgicznego. Pierwszy wielkopostny dzień skupienia (16 marca) połączony był z nabożeństwem Gorzkich żali z kazaniem pasyjnym i sesją wykładową. Ks. mgr lic. Tomasz Zmarzły omówił Biblijne rozumienie nowej ewangelizacji, ks. dr Paweł Pielka Świadectwo chrześcijańskie jako „język” w ewangelizacyjnym posłannictwie dzisiejszego Kościoła. Mszy świętej koncelebrowanej przewodniczył bp dr Grzegorz Kaszak. Na drugi adwentowy dzień skupienia (7 grudnia) złożył się wykład ks. dr. Michała Bordy pt. Miejsce i rola współczesnych mediów $w$ katechezie oraz msza święta koncelebrowana pod przewodnictwem ks. Leonarda Zagórskiego, dziekana dekanatu św. Franciszka z Asyżu w Łazach. Okolicznościowe wystąpienie wygłosił ks. Jan Szkoc nt. zlaicyzowania współczesnego obrazu postaci św. Mikołaja, biskupa. Po mszy świętej dzielono się opłatkiem. 17 października członkowie sosnowieckiego oddziału PTT wzięli udział w obronie rozprawy doktorskiej ks. Dariusza Piaseckiego pt. Spotkanie tradycji pogańskiej z chrześcijańska $w$ „Centonach Homeryckich” na Katolickim Uniwersytecie Lubelskim Jana Pawła II. 6 kwietnia odbyło się spotkanie robocze zarządu sosnowieckiego oddziału. W związku z Rokiem Wiary 
rozpoczęto przygotowania do sympozjum diecezjalnego: Taka jest nasza wiara! Wyzwania ewangelizacyjne dzisiaj. Odbyło się ono 20 kwietnia 2013 roku. W sympozjum wzięli udział biskupi Grzegorz Kaszak i Piotr Skucha. Pod dwóch głównych wykładach: Mądrość wiary (prof. Wojciech Giertych OP, teolog Domu Papieskiego w Rzymie) i Co to znaczy być człowiekiem wierzacym? (prof. Jacek Salij OP, Uniwersytet Kardynała Stefana Wyszyńskiego w Warszawie) oraz dyskusji odbyły się spotkania w grupach tematycznych, w których analizowano przekaz wiary w rodzinie (prof. Jacek Salij, Michał i Agnieszka Barszczewscy, ks. dr Andrzej Cieślik), wiara a kultura (prof. Wojciech Giertych, Dariusz Niebudek, ks. dr Paweł Sobierajski), Nowa Ewangelizacja (ks. Artur Sepioło, Roman Solecki, ks. dr Włodzimierz Skoczny), wyzwania dla wiary młodych (ks. Stanisław Kołakowski, Magdalena Żyła, ks. dr Paweł Pielka), wiara a media (Jan Pospieszalski, ks. Marek Gancarczyk, ks. Paweł Rozpiątkowski), wiara bez uczynków jest martwa (ks. Jacek Stryczek, Agnieszka Bartnik, Ewa Stasikowska-Dutka, ks. dr Wojciech Kowalski), wiara a katecheza (ks. dr Grzegorz Noszczyk, dr Elżbieta Tkocz, ks. dr Michał Borda).

\subsection{Oddział w Szczecinie}

Został powołany do istnienia 8 grudnia 2011 roku i działa przy Wydziale Teologicznym Uniwersytetu Szczecińskiego. Kierownikiem oddziału jest ks. prof. dr hab. Andrzej Offmański. W drugim roku swojej działalności oddział szczeciński zorganizował 3 konferencje naukowe. 10-11 czerwca w Trzęsaczu odbyła się konferencja naukowa pt. Współczesność - wiara - katecheza. Katecheza $w$ stużbie wiary, w której specjaliści z całej Polski analizowali problem wiary we współczesnym świecie (prof. Andrzej Potocki OP z Uniwersytetu Warszawskiego, ks. prof. Zdzisław Kroplewski z Uniwersytetu Szczecińskiego), wiarę jako pierwszorzędny cel katechezy (ks. prof. Janusz Bujak z Uniwersytetu Szczecińskiego, ks. prof. Jan Szpet z Uniwersytetu Adama Mickiewicza oraz możliwości pogłębienia wiary dzisiaj w katechezie, także w szkolnym nauczaniu religii (ks. prof. Roman Murawski - Warszawa, ks. dr Marek Korgul z Papieskiego Wydziału Teologicznego we Wrocławiu). Teksty wystąpień ukaża się w „Colloquia Theologica Ottoniana”. Druga konferencja naukowa zorganizowana przez oddział szczeciński wespół 
z Instytutem św. Siostry Benedykty od Krzyża (Edith Stein) odbyła się 19 października w Zielonej Górze na temat: Język Kościoła posoborowego. Z kolei 16 listopada w ramach zamknięcia Roku Wiary w budynku Kurii Metropolitalnej w Szczecinie odbyła się konferencja naukowa członków PTT na temat: Wiara we współczesnej rzeczywistości. Wykłady o aspekcie doktrynalnym wiary (fides quae creditur) przedstawił ks. prof. Janusz Bujak, a o aspekcie pastoralnym wiary ks. prof. Andrzej Draguła.

\subsection{Oddział w Toruniu}

Zapoczątkował swoje istnienie 20 stycznia 2012 roku. Pracami oddziału kieruje ks. prof. dr. hab. Dariusz Zagórski. W roku sprawozdawczym odbyły się dwa spotkania: 16 października z odczytem kierownika oddziału pt. Św. Augustyn jako duszpasterz w świetle „Sermones” św. Augustyna i 2 grudnia poświęcone przygotowaniu dwóch konferencji, których współorganizatorem będzie oddział toruński: 15-16 maja pt. Wiara i kultura. Hermeneutyka kulturowa i rekonfiguracja oraz 7-8 czerwca: Camino Polaco. Teologia, sztuka, historia, teraźniejszość. I Międzynarodowa Konferencja Poświęcona Szlakom św. Jakuba. Członkowie oddziału brali udział w wielu sympozjach naukowych i mogą się poszczycić wydaniem kilku książek i artykułów naukowych.

\section{Uwagi końcowe}

Do najważniejszych dokonań zarządu Polskiego Towarzystwa Teologicznego w roku sprawozdawczym należy zaliczyć powstanie Oddziału we Włocławku i zaawansowanie prac nad powstaniem Oddziału w Pelplinie. Warto dodać, że w obecnej kadencji, a więc w latach 20112013 powstały oddziały w Szczecinie i Toruniu. Dzięki temu Polskie Towarzystwo Teologiczne faktycznie rozciągnęło swoją działalność na całą Polskę. Mamy nadzieję, że prowadzone rozmowy zaowocują powstaniem dalszych oddziałów terenowych.

Godna podkreślenia jest bliska współpraca z Międzynarodową Wystawą Budownictwa i Wyposażenia Kościołów, Sztuki Sakralnej i Dewocjonaliów 
SACROEXPO. Pozwala to członkom towarzystwa kształtować i inspirować współczesną sztukę sakralną. Ważnym osiągnięciem jest także zrealizowanie projektu pt. Nadanie międzynarodowego charakteru kwartalnikowi „Ruch Biblijny i Liturgiczny” finansowanego przez Ministra Nauki i Szkolnictwa Wyższego w ramach konkursu INDEX PLUS.

Na szczególne uznanie zasługuje ożywiona działalność oddziałów w Kielcach, Sandomierzu i Sosnowcu oraz sekcji specjalistycznych: biblijnej, sztuki sakralnej, teologii fundamentalnej i misjologicznej. Godne podkreślenia jest także powołanie Sekcji Teologii Życia Konsekrowanego.

Polskie Towarzystwo Teologiczne jest publicznym stowarzyszeniem wiernych o zasięgu ogólnopolskim. Stąd też zarząd na ręce kard. Stanisława Dziwisza oraz księży biskupów obecnych na walnym zebraniu składa serdeczne podziękowanie Konferencji Episkopatu Polski za troskę władz kościelnych o rozwój towarzystwa. Zarząd dziękuje również wszystkim aktywnym członkom towarzystwa, którzy mimo wielorakich trudności czynią wszystko, aby działalność towarzystwa była kontynuowana i służyła dalszemu uwrażliwieniu polskiego społeczeństwa na myśl teologiczną. 